\title{
STRATEGI PENINGKATAN KUALITAS PELAYANAN BAITUL MALL WAT TAMWIL (BMT) DI KOTA PEKANBARU MELALUI INTEGRASI SERVQUAL DAN IMPORTANCE PERFORMANCE ANALYSIS (IPA)
}

\author{
Zulfadli Hamzah \\ Fakultas Agama Islam, Universitas Islam Riau \\ Email: zulfadlihamzah@fis.uir.ac.id
}

\begin{abstract}
ABSTRAK
Untuk meningkatkan pangsa pasarnya BMT perlu menganalisa faktor-faktor apa saja yang mempengaruhi masyarakat untuk bersedia menjadi nasabah di BMT. Salah satu faktornya adalah kualitas pelayanan yang diberikan oleh BMT kepada nasabahnya. Metode penelitian ini adalah penelitian kuantitatif dengan menggunakan pendekatan SERVQUAL dan Importance Performance Analysis (IPA). Adapun Populasi dalam penelitian ini adalah seluruh nasabah BMT yang ada di Kota Pekanbaru dan jumlah sampel sebanyak 200 responden dengan menggunakan teknik sampling Roscoe. Hasil penelitian ini menemukan beberapa temuan atribut layanan yang harus dipertahankan lagi kinerjanya oleh BMT di kota Pekanbaru adalah BMT memiliki lokasi yang strategis dan terjangkau, karyawan BMT senantiasa ramah dan santun dalam melayani nasabah, karyawan BMT cepat tanggap dalam menjawab pertanyaan nasabah seputar produk BMT, karyawan BMT cepat tanggap dalam menyelesaikan keluhan dan permasalahan yang dialami oleh nasabah, karyawan BMT senantiasa mampu memenuhi kebutuhan nasabah secara cepat, karyawan BMT senantiasa tepat dalam bertindak dan sangat minim melakukan kesalahan, dan karyawan BMT mampu memberikan informasi yang tepat kepada nasabah seputar produk BMT, Waktu yang dibutuhkan dalam menangani masalah nasabah selalu cepat dan masalah terselesaikan sesuai waktu yang dijanjikan, karyawan BMT mampu melayani nasabah tepat waktu sehingga mempersingkat waktu antri nasabah dalam menunggu layanan, karyawan BMT memiliki kemampuan komunikasi yang sangat bagus, dan kompetensi yang dimiliki oleh karyawan BMT sangat baik.
\end{abstract}

Kata Kunci : Baitul Maal wat Tamwil, Kualitas Layanan, Kepuasan Nasabah.

\begin{abstract}
For increasing its market share, BMT needs to analyze what factors affect people to have a willingness to be a customer in BMT. One of the factors is the service quality provided by BMT to the customer. The method of this study was quantitative using the SERVQUAL approach and ImportancePerformance Analysis (IPA). The population in this study was all customers of BMT in Pekanbaru and the total sample was 200 respondents using the Roscoe sampling technique. The result of this study found some findings referring to service attributes with the performance that BMT in Pekanbaru should maintain. They were the strategic and affordable location of BMT, BMT friendly and polite employees in serving customers, BMT fast response employees in answering the customers' inquiries about BMT products, BMT fast response employees in resolving the complaints and problems faced by the customers, BMT employees' ability to fulfill the customers' needs quickly, BMT employees' accurate action with very few mistakes, and BMT employees' ability to provide accurate information to the customers about BMT products. The time required in dealing with customers' problems quickly and the problems were resolved based on the time committed by the employees. The BMT employees were able to serve the customers on time, so it could reduce wait times at queue lines for getting services. BMT employees have excellent communication skills and competencies.
\end{abstract}

Keyword : Baitul Mall Wat Tamwil, Service Quality, Customer Satisfaction. 


\section{PENDAHULUAN}

BMT ialah lembaga keuangan syariah yang beroperasi menggunakan gabungan konsep "Baitul Maal" dan "Baitul Tamwil" dengan target operasionalnya fokus kepada sektor Usaha Kecil Menengah (UKM). Konsep Baitul maal berarti BMT berperan sebagai lembaga sosial keagamaan yang mempunyai fungsi untuk menerima dana Zakat, Sedekah, Infaq dan Waqaf dan menyalurkan kepada yang berhak menerima dana tersebut. Sedangkan pada konsep Baitul Tamwil, BMT mempunyai peranan sebagai lembaga bisnis maupun lembaga keuangan yang bertujuan untuk mencari keuntungan (profit oriented) seperti membuka Toserba (toko serba ada) atau menawarkan produk simpan pinjam ke masyarakat. Namun jika kita lihat prakteknya dilapangan, BMT lebih cenderung berperan sebagai lembaga keuangan shariah yang menawarkan produk simpan pinjam ke masyarakat yang berlandaskan pada prinsip syariah.

Pada hakikatnya konsep BMT tersebut sudah ada di Indonesia sejak tahun 1992 yang dipelopori oleh Aries Mufti dengan mendirikan BMT Bina Insan Kamil di Jakarta Pusat. Walau bagaimanapun, BMT secara resmi didirikan pada tahun 1995 setelah Bank Muamalat Indonesia (BMI) sebagai Bank Islam pertama di Indonesia dibentuk. Pendirian BMT ketika itu didirikan berdasarkan inisiatif dari ICMI (Ikatan Cendikiawan Muslim Indonesia), MUI (Majlis Ulama Indonesia) dan BMI (Bank Muamalat Indonesia). Dan BMT mulai beroperasi di bawah pengawasan PINBUK (Pusat Inkubasi Usaha Kecil) pada tahun yang sama.

Kota Pekanbaru adalah ibukota provinsi Riau yang mayoritas penduduknya beragama Islam dan berbudaya melayu dengan luas wilayah 8.915.016 KM2 dan jumlah penduduk 1,2 juta jiwa (2018) yang sebagian besar penduduknya bekerja di sektor jasa dan perdagangan. Dalam beberapa tahun terakhir kota pekanbaru mengalami perkembangan yang pesat baik itu dari sektor pembangunan maupun sektor perekonomian. Sehingga ini menjadi potensi yang besar untuk perkembangan Baitul Maal Wat Tamwil (BMT) yang ada di Kota pekanbaru. Adapun jumlah BMT yang ada di Kota Pekanbaru adalah sebagai berikut :

Tabel 1. Daftar Baitul Maal Wat Tamwil (BMT) di Kota Pekanbaru

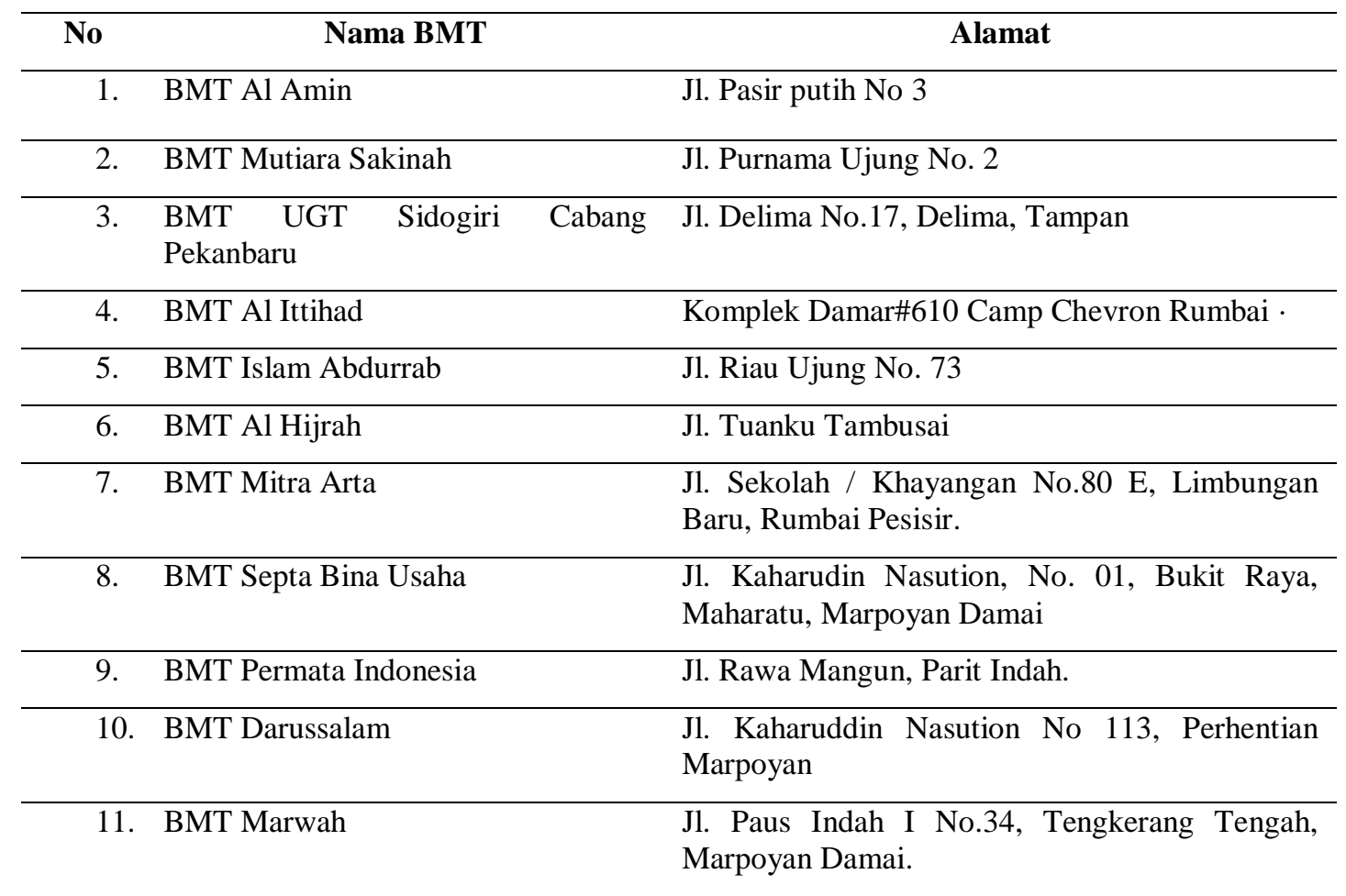


Berdasarkan dari tabel di atas dapat kita ketahui bahwa masih ada 11 unit BMT yang beroperasi di Kota Pekanbaru. Mereka dapat bertahan karena mampu memenuhi permintaan masyarakat dan mendapat kepercayaan dari masyarakat dalam hal pelayanan jasa keuangan.

Untuk meningkatkan pangsa pasarnya, BMT perlu menganalisa faktorfaktor apa saja yang mempengaruhi masyarakat untuk bersedia menjadi nasabah di BMT. Hasil penelitian di Tunisia menunjukkan bahwa kualitas pelayanan memegang peranan penting dalam mempengaruhi keputusan orang untuk memiliki rekening di perbankan syariah (Hoffman \& Bateson, 2002). Hal yang senada juga di ungkapkan oleh Fauzi (2009) bahwa BMT memerlukan langkah-langkah untuk dapat meningkatkan kualitas pelayanan di karenakan pentingnya kualitas bagi suatu perusahaan Khususnya BMT supaya dapat bertahan dan bersaing dengan lembaga keuangan syariah lainnya. Sehingga, kualitas pelayanan sekarang ini mengacu pada penilaian pelanggan tentang inti dari pelayanan yang mereka terima bukan hanya melihat dari sekedar kualitas produk yang ditawarkan aja. Melainkan masyarakat sekarang cenderung lebih membutuhkan layanan prima dan mereka lebih senang menikmati kenyamanan pelayanan.

\section{TINJAUAN PUSTAKA}

\section{Kualitas Pelayanan}

Kualitas layanan adalah salah satu penentu penting keberhasilan lembaga keuangan terutama BMT, namun seringkali kualitas layanan sangat sulit untuk di ukur karena karakteristiknya yang khas (Hoffman dan Bateson, 2002). Model konseptual kualitas layanan pertama kali diperkenalkan oleh Parasuraman et al, (1985). Model ini terdiri dari banyak dimensi seperti: keandalan, daya tanggap, kompetensi, sopan santun, kredibilitas, keamanan, akses, komunikasi, dan pemahaman kualitas layanan pelanggan. Kemudian, Parasuraman et al, (1985) merevisi kerangka kerja sebelumnya dan kualitas layanan yang dianggap konseptual sebagai penilaian global, atau sikap, berkaitan dengan keunggulan layanan yang dikenal sebagai SERVQUAL. Skala pengukuran ini telah secara luas digunakan sebagai instrumen umum untuk mengukur kualitas layanan di Indonesia. Servqual terdiri dari 5 dimensi diantaranya :

1. Bukti fisik (tangibles) : Merupakan daya tarik fisik suatu pelayanan yang biasanya dilihat melalui daya tarik fasilitas fisik, perlengkapan, material yang digunakan dan penampilan karyawan. Atribut bukti fisik ini ada empat, yaitu:

- Peralatan modern.

- Fasilitas yang berdaya tarik visual.

- Karyawan yang berpenampilan rapi dan professiona.

- Materi-materi berkaitan dengan jasa yang berdaya tarik visual.

2. Kehandalan (reliability) : Merupakan kemampuan perusahaan memberikan pelayanan yang akurat tanpa membuat kesalahan dan diberikan dalam waktu yang tepat. Atribut dari realibilitas ini ada lima yaitu :

- Menyediakan jasa sesuai yang dijanjikan.

- Dapat diandalkan dalam menengani masalah jasa pelanggan.

- Menyampaikan jasa secara benar semenjak pertama kali.

- Menyampaikan jasa sesuai dengan waktu yang dijanjikan.

- Menyimpan catatan atau dokumen tanpa kesalahan.

3. Daya tanggap (responsiveness) : Merupakan kesediaan dan kemampuan karyawan untuk membantu pelanggan dalam memberikan informasi pelayanan dan pemecahan masalah pelayanan, 
atribut dari daya tanggap ini ada empat, yaitu:

- Menginformasikan kepada pelanggan tentang kepastian waktu penyampaian jasa.

- Layanan yang segera atau cepat bagi pelanggan.

- Kesediaan untuk membantu pelanggan.

- Kesiapan untuk merespon permintaan pelanggan.

4. Jaminan (assurance) : perilaku para karyawan mampu menumbuhkan kepercayaan pelanggan terhadap perusahaan dan perusahaan bisa menciptakan rasa aman bagi para pelanggannya. Atribut dari jaminan ini ada empat, yaitu:

- Karyawan yang menumbuhkan rasa percaya para pelangga.

- Membuat pelanggan merasa aman sewaktu melakukan transaksi.

- Karyawan yang secara konsisten bersikap sopan.

- Karyawan yang mampu menjawab pertanyaan pelanggan.

5. Empati (emphaty) : Berarti perusahaan memahami masalah para pelanggannya dan bertindak demi kepentingan pelanggan, serta memberikan perhatian personal kepada para pelanggan dan memiliki jam operasi yang nyaman. atribut dari empat ini ada lima, yaitu:

- Memberikan perhatian individual kepada para pelanggan.

- Karyawan yang memperlakukan pelanggan secara penuh perhatian.

- Sungguh-sungguh mengutamakan kepentingan pelanggan.

- Karyawan yang memahami kebutuhan pelanggan.

- Waktu operasi (jam kantor) yang nyaman.

\section{Penelitian Terdahulu}

Beberapa penelitian yang menunjang pentingnya kualitas pelayanan dalam suatu pemasaran produk atau jasa. Kualitas layanan juga secara luas dianggap sebagai penggerakpemasaran perusahaan dan kinerja keuangan (Amin dan Isa, 2008). Lee et al, (2000) membuat kontribusi substansial terhadap literatur kualitas layanan dengan menggunakan model SERVQUAL dan mengidentifikasi faktor-faktor penentu kualitas layanan yang dirasakan. Lee et al, (2000) berusaha untuk menghubungkan penentu kualitas layanan untuk kepuasan bagi perusahaan yang berorientasi layanan. Para penulis menemukan itu kualitas layanan yang dirasakan adalah anteseden kepuasan. Namun begitu, para peneliti seperti Newman (2001) mengidentifikasi kelemahan serius dalam nilai SERVQUAL sebagai ukuran kualitas layanan dan sebagai alat diagnostik di sektor perbankan Amerika Serikat.

Selanjutnya Flavian et al, (2004) dan Jayawardhena (2004) mengidentifikasi faktor tambahan seperti akses ke layanan, layanan yang ditawarkan, keamanan, dan reputasi untuk mengukur citra kualitas layanan perusahaan. Beberapa studi lainnya yang mendefinisikan dan mengukur dimensi kualitas layanan sebagai indikator kinerja (Vera dan Trujillo, 2013). Joseph et al, (1999) menggunakan indikator kualitas layanan di sektor perbankan dan meneliti dampak teknologi pada pemberian layanan. Jabnoun dan Al-Tamimi (2003) memodifikasi model SERVQUAL untuk mengukur kualitas layanan yang dirasakan dari bank komersial di Uni Emirat Arab. Dalam studi ini, peneliti menganalisa kepentingan relatif dari setiap dimensi kualitas layanan tetapi mereka tidak hubungkan dimensi-dimensi ini dengan kepuasan jasa. Amin dan Isa (2008), mengukur dan menganalisa Kualitas pelayanan bank-bank syariah di Malaysia. Dusuki dan Abdullah (2007) menguji faktorfaktor tersebutmemotivasi pelanggan untuk berurusan dengan bank syariah dalam sistem perbankan ganda. 
Jabnoun dan Khalifa (2005) menguji ukuran layanan yang disesuaikan kualitas di bank konvensional dan syariah di UAE. Kumar et al, (2010) menganalisa perbedaan kualitas layanan antara bank konvensional dan bank syariah di Malaysia dan ditemukan perbedaan menarik antara dua sistem perbankan dalam hal tangibilitas dan kesenjangan kualitas pelayanan. Temuan ini belum divalidasi dalam penelitian serupa.

\section{METODE PENELITIAN}

Penelitian ini menggunakan pendekatan kuantitatif. Penelitian kuantitatif biasa dikenal dengan penelitian yang bersifat angka-angka (Abdullah \& Saebani, 2014), Metode penelitian ini menggunakan pendekatan SERVQUAL dan Importance Performance Analysis (IPA) untuk mengetahun kepuasan nasabah BMT terhadap pelayanan yang diberikan oleh karyawan BMT.

\section{Populasi dan Sampel}

Populasi dalam penelitian ini adalah seluruh nasabah BMT yang ada di Kota Pekanbaru. Penelitian ini menggunakan teknik sampling Roscoe dimana jumlah sampling diperoleh sebanyak jumlah variabel (5) di kali dengan jumlah sampel minimum (30) oleh itu diperoleh total 150 responden. Untuk memaksimalkan hasil penelitian maka dibulatkan menjadi 200 responden/nasabah BMT. Teknik pengambilan sampel yang digunakan adalah teknik sampling probabilitas dengan sistem acak terhadap seluruh nasabah BMT yang ada di Pekanbaru.

\section{Metode Importance and Performance Analysis (IPA)}

Dalam teknik IPA ini responden diminta untuk menilai tingkat kepentingan atribut layanan dan tingkat kinerja pada masing-masing atribut layanan nasabah. Analisis IPA dilakukan dengan menggunakan SPSS 22 yang menyediakan fasilitas analisis graphs scatter/dot yang hasilnya berupa gambar diagram kartesius. Diagram kartesius merupakan suatu bangun persegi yang dibagi dalam empat bagian dengan dibatasi oleh dua buah garis yang berpotongan tegak lurus pada titik-titik ( $\mathrm{X}$ dan $\mathrm{Y}$ ), dan $\mathrm{X}$ merupakan rata-rata dari skor tingkat penilaian kinerja sedangkan $\mathrm{Y}$ adalah rata-rata dari skor tingkat kepentingan. Tujuan analisis IPA ini adalah untuk mengidentifikasi atribut kepentingan layanan nasabah berada dikuadran A, B, C, atau D dalam diagram kartesius.

Berdasarkan data yang akan diperoleh dari hasil penilaian responden terhadap variabel importance dan performance dari masing-masing layanan BMT yang ada di Pekanbaru dilakukan perhitungan kesesuaian antara tingkat kepentingan dari nasabah terhadap tingkat kinerja pelayanan BMT. Tingkat kesesuaian adalah hasil yang diperoleh dari perbandingan antara skor kinerja dengan skor kepentingan. Dari tingkat kesesuaian yang diperoleh ini diharapkan dapat dipakai sebagai acuan dalam menentukan prioritas peningkatan atribut kualitas layanan yang mempengaruhi penilaian mahasiswa terhadap kinerja layanan yang diterima.

Adapun rumus yang digunakan adalah sebagai berikut (Supranto, 2011) :

$$
\mathrm{Tki}=\mathrm{Xi} / \mathrm{Yi} \times 100 \%
$$

\section{Dimana:}

Tki $=$ Tingkat Kesesuaian Responden

$\mathrm{Xi}=$ Skor Penilaian Kinerja

Yi $=$ Skor penilaian Kepentingan

Tahap selanjutnya adalah menghitung skor rata-rata kualitas layanan BMT dengan menggunakan rumus sebagai berikut:

$$
{ }^{-} \mathrm{X}=\left(\sum \mathrm{Xi}\right) / \mathrm{n}{ }^{-} \mathrm{Y}\left(\sum \mathrm{Yi}\right) / \mathrm{n}
$$

Dimana;

$\mathrm{X}=$ Skor rata-rata tingkat plaksanaan/kinerja

$\mathrm{Y}=$ Skor rataan tingkat kepentingan

$\mathrm{n}=$ Jumlah responden $\mathrm{X} Y$ 


\section{HASIL PENELITIAN DAN \\ PEMBAHASAN}

Analisis Gap

Tabel 2. Hasil Analisis Gap

\begin{tabular}{|c|c|c|c|c|}
\hline No & Indikator & Important & Performance & GAP \\
\hline \multicolumn{5}{|c|}{ Tangible } \\
\hline 1 & $\begin{array}{l}\text { Karyawan BMT Berpakaian Sopan dan Rapi sesuai } \\
\text { dengan Syariat. }\end{array}$ & 4.51 & 4.34 & -0.176 \\
\hline 2 & BMT memiliki lokasi yang strategis dan terjangkau & 4.56 & 4.41 & -0.156 \\
\hline 3 & Kebersihan kantor BMT terjaga dengan sangat baik & 4.49 & 4.31 & -0.186 \\
\hline 4 & $\begin{array}{l}\text { Peralatan kantor dan fasilitas yang digunakan untuk } \\
\text { melayani nasabah tersedia dengan lengkap }\end{array}$ & 4.53 & 4.18 & -0.352 \\
\hline 5 & $\begin{array}{l}\text { BMT memiliki system pelayanan online yang mudah } \\
\text { untuk digunakan }\end{array}$ & 4.27 & 3.87 & -0.392 \\
\hline \multicolumn{5}{|c|}{ Emphaty } \\
\hline 1 & $\begin{array}{l}\text { Karyawan BMT senantiasa memberikan perhatian } \\
\text { yang baik kepada seluruh nasabah dalam pelayanan }\end{array}$ & 4.44 & 4.26 & -0.181 \\
\hline 2 & $\begin{array}{l}\text { Karyawan BMT tidak pernah memilih-milih dalam } \\
\text { melayani nasabah }\end{array}$ & 4.34 & 4.16 & -0.181 \\
\hline 3 & $\begin{array}{l}\text { BMT senantiasa menyediakan layanan yang } \\
\text { diharapkan oleh nasabah }\end{array}$ & 4.47 & 4.38 & -0.090 \\
\hline 4 & $\begin{array}{l}\text { Karyawan BMT senantiasa ramah dan santun dalam } \\
\text { melayani nasabah }\end{array}$ & 4.57 & 4.28 & -0.296 \\
\hline 5 & $\begin{array}{l}\text { Karyawan BMT memahami kebutuhan dan mampu } \\
\text { menyelesaikan setiap masalah dan keluhan nasabah }\end{array}$ & 4.49 & 4.21 & -0.276 \\
\hline \multicolumn{5}{|c|}{ Responsiveness } \\
\hline 1 & $\begin{array}{l}\text { Karyawan BMT cepat tanggap dalam menjawab } \\
\text { pertanyaan nasabah seputar produk BMT }\end{array}$ & 4.64 & 4.43 & -0.206 \\
\hline 2 & $\begin{array}{l}\text { Karyawan BMT cepat tanggap dalam menyelesaikan } \\
\text { keluhan dan permasalahan yang dialami oleh nasabah }\end{array}$ & 4.64 & 4.57 & -0.070 \\
\hline 3 & $\begin{array}{l}\text { Karyawan BMT senantiasa mampu memenuhi } \\
\text { kebutuhan nasabah secara cepat }\end{array}$ & 4.64 & 4.36 & -0.276 \\
\hline 4 & $\begin{array}{l}\text { Karyawan BMT senantiasa tepat dalam bertindak dan } \\
\text { sangat minim melakukan kesalahan }\end{array}$ & 4.64 & 4.40 & -0.236 \\
\hline 5 & $\begin{array}{l}\text { Karyawan BMT mampu memberikan informasi yang } \\
\text { tepat kepada nasabah seputar produk BMT }\end{array}$ & 4.64 & 4.25 & -0.392 \\
\hline \multicolumn{5}{|c|}{ Reliability } \\
\hline 1 & $\begin{array}{l}\text { Informasi yang diberikan dalam setiap promosi yang } \\
\text { dilakukan oleh BMT melalui brosur maupun media } \\
\text { lainnya senantiasa tepat dan akurat }\end{array}$ & 4.49 & 4.21 & -0.281 \\
\hline 2 & $\begin{array}{l}\text { Informasi yang diberikan oleh karyawan BMT dalam } \\
\text { melayani nasabah juga akurat dan dapat } \\
\text { dipertanggungjawabkan }\end{array}$ & 4.47 & 4.25 & -0.216 \\
\hline 3 & $\begin{array}{l}\text { Waktu yang dibutuhkan dalam menangani masalah } \\
\text { nasabah selalu cepat dan masalah terselesaikan sesuai } \\
\text { waktu yang dijanjikan }\end{array}$ & 4.59 & 4.33 & -0.261 \\
\hline 4 & Karyawan BMT memiliki pengetahuan yang luas & 4.53 & 4.32 & -0.211 \\
\hline 5 & $\begin{array}{l}\text { Karyawan BMT mampu melayani nasabah tepat } \\
\text { waktu sehingga mempersingkat waktu antri nasabah }\end{array}$ & 4.63 & 4.26 & -0.372 \\
\hline
\end{tabular}


2021, Jurnal Tabarru' : Islamic Banking and Finance 4 (2) : 573 - 584

\begin{tabular}{|c|c|c|c|c|}
\hline \multicolumn{5}{|c|}{ dalam menunggu layanan } \\
\hline \multicolumn{5}{|c|}{ Assurance } \\
\hline 1 & $\begin{array}{l}\text { Karyawan BMT memiliki kemampuan komunikasi } \\
\text { yang sangat bagus }\end{array}$ & 4.64 & 4.23 & -0.407 \\
\hline 2 & $\begin{array}{l}\text { Karyawan BMT senantiasa bertindak professional dan } \\
\text { kredibilitasnya tidak diragukan }\end{array}$ & 4.53 & 4.20 & -0.332 \\
\hline 3 & $\begin{array}{l}\text { Bertransaksi dan menggunakan layanan produk BMT } \\
\text { merupakan pilihan yang aman }\end{array}$ & 4.55 & 4.38 & -0.176 \\
\hline 4 & $\begin{array}{l}\text { Karyawan BMT memiliki etika yang baik dalam } \\
\text { melayani nasabah }\end{array}$ & 4.56 & 4.36 & -0.196 \\
\hline 5 & $\begin{array}{l}\text { Kompetensi yang dimiliki oleh karyawan BMT } \\
\text { sangat baik }\end{array}$ & 4.52 & 4.38 & -0.136 \\
\hline
\end{tabular}

\section{Sumber : Data Olahan (2021)}

Berikut adalah hasil
mentukatkan nerhitungan
nilai (Importance) dan performansi (Performance) responden terhadap seluruh kriteria penilaian serta kesenjangan yang didapat antara performansi (Performance) dan ekspektasi/Importance (skor gap). Nilai gap atau kesenjangan dapat terjadi ketika terdapat selisih antara harapan dan kenyataan yang pelanggan terima. Nilai gap terdiri dari dua yaitu gap positif dan gap negatif. Berdasarkan data pada tabel di atas, ke-25 kriteria penilaian akan kualitas pelayanan pada pelayanan Baitul Maal wat Tamwil (BMT) di kota Pekanbaru memperoleh hasil gap yang negatif untuk semua kriteria, hal tersebut menunjukan adanya ketidakpuasan dengan kualitas pelayanan yang didapatkan oleh nasabah BMT. Kesenjangan yang paling jauh antara harapan dan kenyataan yang diterima oleh pelanggan adalah pada atribut "Karyawan BMT memiliki kemampuan komunikasi yang sangat bagus" sedangkan untuk atribut dengan kesenjangan/gap paling kecil adalah "Karyawan BMT cepat tanggap dalam menyelesaikan keluhan dan permasalahan yang dialami oleh nasabah".

Matrik Importance Performance Analysis (IPA)

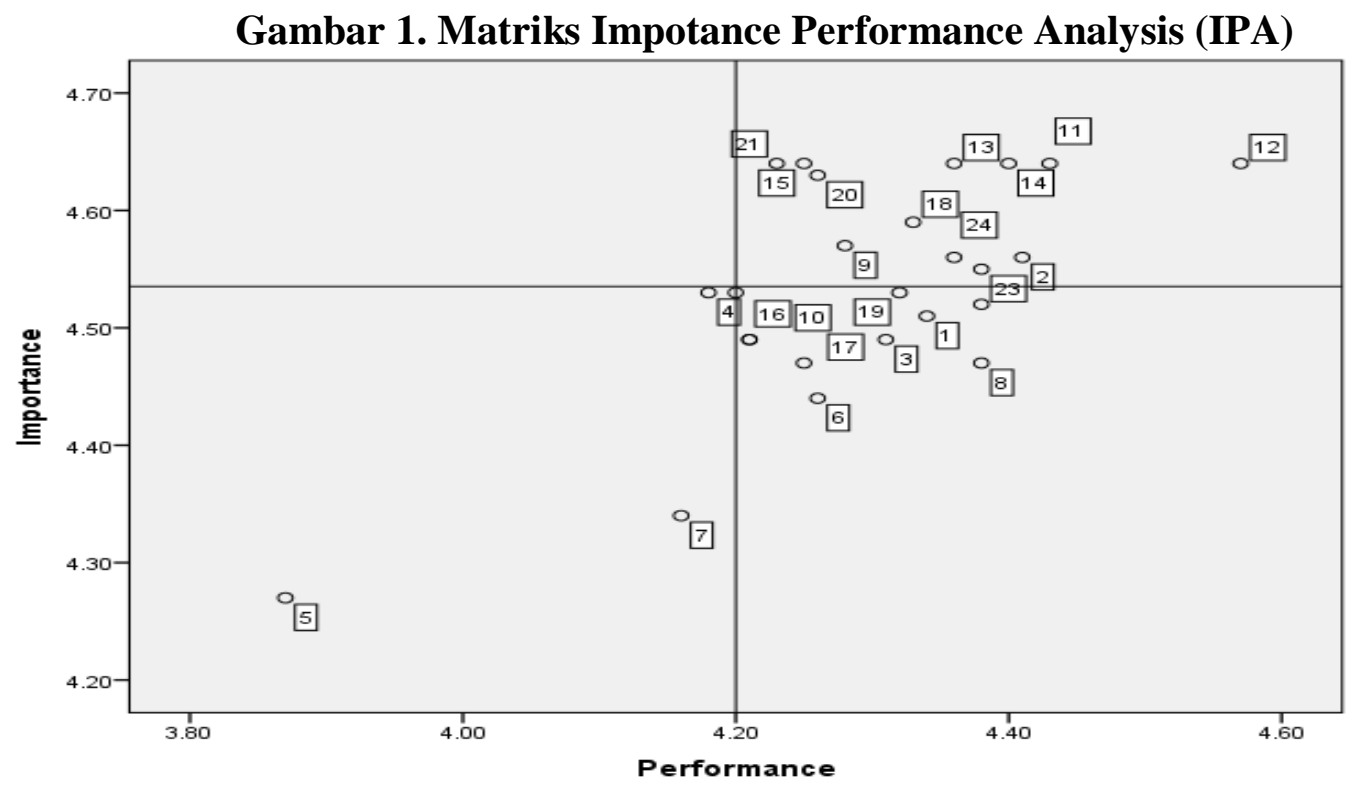

Sumber : Data Olahan (2021) 
Hasil matriks Importance Performance Analysis (IPA) membagi hasil tanggapan responden ke dalam 4 kuadran yang terdiri dari :

Kuadran I memetakan atribut layanan yang harus menjadi prioritas perbaikan karena nasabah mempunyai nilai harapan yang tinggi namun tingkat kinerjanya dinilai masih belum sesuai yang diharapkan oleh nasabah BMT di Kota Pekanbaru. Berdasarkan dari gambar matrik IPA diatas tidak terdapat atribut kualitas pelayanan BMT pada kuadran ini.

Kuadran II menunjukan keberadaan atribut layanan yang juga dianggap penting oleh nasabah BMT dan kinerjanya sudah dianggap baik, oleh karenanya BMT di Kota Pekanbaru harus mempertahankan kinerja atribut ini supaya dapat terus menjadi lebih baik dan terus memenuhi apa yang menjadi harapan nasabah BMT. Atribut yang berada pada kuadran ini terdiri dari variabel bukti fisik/Tangible (BMT memiliki lokasi yang strategis dan terjangkau), variabel empati (Karyawan BMT senantiasa ramah dan santun dalam melayani nasabah), variabel responsiveness (Karyawan BMT cepat tanggap dalam menjawab pertanyaan nasabah seputar produk BMT, Karyawan BMT cepat tanggap dalam menyelesaikan keluhan dan permasalahan yang dialami oleh nasabah, Karyawan BMT senantiasa mampu memenuhi kebutuhan nasabah secara cepat, Karyawan BMT senantiasa tepat dalam bertindak dan sangat minim melakukan kesalahan, Karyawan BMT mampu memberikan informasi yang tepat kepada nasabah seputar produk BMT), variabel reliability (Waktu yang dibutuhkan dalam menangani masalah nasabah selalu cepat dan masalah terselesaikan sesuai waktu yang dijanjikan, Karyawan BMT mampu melayani nasabah tepat waktu sehingga mempersingkat waktu antri nasabah dalam menunggu layanan), dan variabel assurance (Karyawan BMT memiliki kemampuan komunikasi yang sangat bagus, Kompetensi yang dimiliki oleh karyawan BMT sangat baik).
Kuadran III menunjukkan atribut layanan dimana nasabah BMT tidak mempunyai harapan terlalu tinggi sehingga tingkat kepentingannya tidak mendapat penilaian tinggi dan kinerjanya juga dinilai biasa-biasa saja, sehingga tidak harus memberikan fokus perbaikan untuk atribut layanan yang ada dalam kuadran ini. Adapun atribut layanan yang berada pada kuadran ini terdiri dari variabel bukti fisik (Peralatan kantor dan fasilitas yang digunakan untuk melayani nasabah tersedia dengan lengkap, BMT memiliki sistem pelayanan online yang mudah untuk digunakan), variabel empati (Karyawan BMT tidak pernah memilih-milih dalam melayani nasabah), dan variabel Assurance (Karyawan BMT senantiasa bertindak professional dan kredibilitasnya tidak diragukan).

Kuadran IV menunjukan keberadaan atribut layanan yang menurut nasabah BMT kinerjanya sudah baik bahkan cenderung melebihi apa yang diingikan nasabah karena sebenarnya nasabah tidak terlalu mempunyai harapan pada atribut layanan ini, sehingga tidak perlu memeberikan fokus pada atribut yang berada dalam kuadran ini. terdapat beberapa atribut layanan yang berada dalam dimensi ini yaitu variabel bukti fisik/tangible (Karyawan BMT Berpakaian Sopan dan Rapi sesuai dengan Syariat, Kebersihan kantor BMT terjaga dengan sangat baik), variabel Empathy (Karyawan BMT senantiasa memberikan perhatian yang baik kepada seluruh nasabah dalam pelayanan, BMT senantiasa menyediakan layanan yang diharapkan oleh nasabah, Karyawan BMT memahami kebutuhan dan mampu menyelesaikan setiap masalah dan keluhan nasabah), variabel Reliability (Informasi yang diberikan dalam setiap promosi yang dilakukan oleh BMT melalui brosur maupun media lainnya senantiasa tepat dan akurat, Informasi yang diberikan oleh karyawan BMT dalam melayani nasabah juga akurat dan dapat dipertanggungjawabkan, Karyawan BMT memiliki pengetahuan yang luas) dan variabel Assurance (Bertransaksi dan menggunakan layanan produk BMT merupakan pilihan yang aman). 
Melalui hasil penelitian ini memberikan kontribusi penting bagi Baitul Mall wat Tamwil (BMT) untuk fokus dalam meningkatkan kualitas layanan yang dimiliki dalam hal mencapai kepuasan nasabah. Importance Performance Analysis (IPA) Matrix pada Kuadran I menjadi perhatian penting oleh BMT untuk dilakukan perbaikan dan mengambil tindakan untuk meningkatkan atribut-atribut layanan pada BMT. Namun, Hasil penelitian ini menunjukkan tidak adanya atribut-atribut layanan BMT yang berada pada kuadran I yang bermakna bahwa tidak adanya atributatribut layanan BMT yang menjadi perhatian sangat penting dan prioritas oleh BMT untuk dilakukan perbaikan dan mengambil tindakan yang sifatnya harus di perbaiki segera mungkin atau secepatnya.

Sebagian besar atribut layanan BMT berada pada kuadran II yang menunjukkan keberadaan atribut layanan yang juga dianggap penting oleh nasabah BMT dan kinerjanya sudah di anggap baik, oleh karenanya BMT harus mempertahankan kinerja atribut layanan tersebut supaya dapat terus menjadi lebih baik dan memenuhi apa yang menjadi harapan nasabah BMT. Salah satu atribut layanan yang berada pada kuadran ini adalah BMT memiliki lokasi yang strategis dan terjangkau. Menurut Lupiyoadi (2001) mendefinisikan lokasi adalah tempat dimana perusahaan harus bermarkas melakukan operasi. Pemilihan lokasi mempunyai fungsi yang strategis karena dapat ikut menentukan tercapainya tujuan badan usaha. Menurut Kotler (1999) salah satu kunci sukses adalah lokasi. Lokasi di mulai dengan memilih komunitas, keputusan ini sangat bergantung pada potensi pertumbuhan ekonomis dan stabilitas, persaingan, iklim politik, dan sebagainya. Penelitian yang di lakukan oleh Tyas dan Setiawan (2012) mendapati bahwa terdapat pengaruh yang signifikan lokasi BMT terhadap keputusan nasabah untuk menabung.

Sedangkan untuk atribut layanan dalam variabel Emphaty terkait Karyawan
BMT senantiasa ramah dan santun dalam melayani nasabah. Kualitas pelayanan seperti ini harus terus di pertahankan bahkan jika perlu di tingkatkan lagi agar nasabah BMT merasa nyaman dan puas terhadap pelayanan yang telah di berikan oleh karyawan BMT. Hal ini akan memberikan dampak terhadap reputasi, kepercayaan dan loyalitas nasabah untuk bertransaksi keuangan melalui lembaga BMT.

Atribut layanan berikutnya yang harus di pertahankan kinerjanya oleh BMT adalah pada variabel responsiveness (karyawan BMT cepat tanggap dalam menjawab pertanyaan nasabah seputar produk BMT, Karyawan BMT cepat tanggap dalam menyelesaikan keluhan dan permasalahan yang dialami oleh nasabah, Karyawan BMT senantiasa mampu memenuhi kebutuhan nasabah secara cepat, karyawan BMT senantiasa tepat dalam bertindak dan sangat minim melakukan kesalahan, dan Karyawan BMT mampu memberikan informasi yang tepat kepada nasabah seputar produk BMT). Variabel responsiveness mendominasi atribut-atribut layanan yang harus di pertahankan kualitas layananannya oleh BMT di kota Pekanbaru. Responsiveness menurut Parasuraman et al., (1985) menggaris bawahi bahwa responsif karyawan dalah satunya terdiri dari kemampuan merespon pelanggan sesuai dengan permintaan mereka, dalam hal ini staf BMT bukan hanya harus memiliki kemampuan merespon yang baik namun waktu respon haruslah cepat. Kecepatan waktu respon ini juga berperan dalam mengurangi waktu tunggu nasabah dalam memperoleh layanan.

Atribut layanan yang harus di pertahankan kinerjanya oleh BMT adalah variabel reliability (Waktu yang dibutuhkan dalam menangani masalah nasabah selalu cepat dan masalah terselesaikan sesuai waktu yang dijanjikan, Karyawan BMT mampu melayani nasabah tepat waktu sehingga mempersingkat waktu antri nasabah dalam menunggu layanan). Hal lain yang biasanya terjadi adalah sebagian besar pelanggan tidak 
keberatan menunggu sebuah layanan jika ada alasan yang masuk akal, seperti sedang melayani pelanggan lain. Namun, jika staf membuat pelanggan menunggu tanpa alasan, seperti staf berbicara satu sama lain atau tidak peduli dengan pelanggan, maka akan mungkin mempengaruhi persepsi kualitas layanan dan pelanggan akan merasa tidak puas (Alzaydi et al., 2018). Untuk itu pengawasan terhadap staf pelayanan perlu dilakukan oleh manajemen BMT agar staf pelayanan melakukan tugas sesuai dengan prosedur dan aturan yang berlaku.

Atribut layanan terakhir yang harus di pertahankan kinerjanya oleh BMT adalah variabel assurance (Karyawan BMT memiliki kemampuan komunikasi yang sangat bagus, Kompetensi yang dimiliki oleh karyawan BMT sangat baik). Menurut Sedarmayanti (2015) komunikasi merupakan hal penting dalam pencapaian dan pemeliharaan sistem pengukuran kinerja. Komunikasi sebaiknya dari berbagai arah, berasal dari top-down, bottom-up, dan secara horizontal, berada di dalam dan lintas organisasi. Mampu berkomunikasi adalah salah satu soft skill penting yang harus dimiliki oleh seorang karyawan di perusahaan. Dengan adanya komunikasi, seorang karyawan bisa dilihat apakah dia memiliki kualitas atau tidak dalam dirinya. Jika kemampuan berkomunikasinya baik maka kualitas diri yang dia miliki baik pula, begitu pun sebaliknya jika kemampuan berkomunikasinya kurang maka kualitas diri yang dia miliki akan dinilai kurang pula. Sedangkan kompetensi adalah kemampuan individu untuk melaksanakan suatu pekerjaan dengan benar dan memiliki keunggulan yang didasarkan pada hal-hal yang menyangkut pengetahuan (knowledge), keahlian (skill), dan sikap (attitude) (Edison et al, 2016). Faktor kompetensi karyawan yang meliputi kesesuaian pengetahuan dan keterampilan dalam pelaksanaan tugas akan memberikan dampak pada kinerja karyawan sebagai perwujudan prestasinya. Penelitian yang di lakukan oleh Krisnandi dan Saputra (2021) menunjukkan bahwa komunikasi dan kompetensi mempunyai pengaruh yang positif dan signifikan terhadap kinerja karyawan.

Berdasarkan dari uraian diatas, ada beberapa langkah yang dapat di lakukan oleh BMT di kota Pekanbaru untuk meningkatkan kepuasan nasabah terhadap pelayanan yang diberikaannya, diantaranya adalah sebagai berikut :

1. Mengadakan pelatihan untuk meningkatkan kualitas pelayanan karyawan BMT.

2. Membuat peraturan atau SOP (standar operasional) mengenai standar kualitas pelayanan BMT seperti halnya di lembaga perbankan.

3. Membuat sistem keluhan nasabah terhadap pelayanan BMT dan melakukan tindak lanjut secara berkala terhadap keluhan nasabah tersebut.

4. Meningkat fasilitas, sarana dan prasarana yang dimiliki oleh BMT dalam melayani nasabahnya.

\section{KESIMPULAN}

Beberapa temuan atribut layanan yang harus dipertahankan lagi kinerjanya oleh BMT di kota Pekanbaru adalah BMT memiliki lokasi yang strategis dan terjangkau, karyawan BMT senantiasa ramah dan santun dalam melayani nasabah, karyawan BMT cepat tanggap dalam menjawab pertanyaan nasabah seputar produk BMT, karyawan BMT cepat tanggap dalam menyelesaikan keluhan dan permasalahan yang dialami oleh nasabah, karyawan BMT senantiasa mampu memenuhi kebutuhan nasabah secara cepat, karyawan BMT senantiasa tepat dalam bertindak dan sangat minim melakukan kesalahan, dan karyawan BMT mampu memberikan informasi yang tepat kepada nasabah seputar produk BMT, Waktu yang dibutuhkan dalam menangani masalah nasabah selalu cepat dan masalah terselesaikan sesuai waktu yang dijanjikan, karyawan BMT mampu melayani nasabah tepat waktu sehingga mempersingkat waktu antri nasabah dalam menunggu layanan, 
karyawan BMT memiliki kemampuan komunikasi yang sangat bagus, dan kompetensi yang dimiliki oleh karyawan BMT sangat baik. Bagi peneliti selanjutnya diharapkan untuk dapat mendesain sebuah model kualitas layanan yang lebih cocok bagi lembaga BMT yang bukan hanya terfokus pada pelayanan karyawan namun juga pelayanan prima dengan bantuan teknologi terutama pada zaman industri 4.0 saat ini.

\section{DAFTAR PUSTAKA}

Abdullah, Boedi., \& Saebani, Beni Ahmad. 2014. Metode Penelitian Ekonomi Islam Muamalah. CV. Pustaka Setia. Bandung.

Alzaydi, Z. M., Al-Hajla, A., Nguyen, B., \& Jayawardhena, C. 2018. A Review of Service Quality and Service Delivery: Towards a Customer CoProduction and Customer Integration Approach. Business Process Management Journal, 24(1), p. 295-328.

Amin, M., \& Isa, Z. 2008. An Examination of The Relationship Between Service Quality Perception and Customer Satisfaction: A SEM Approach towards Malaysian Islamic Banking. International Journal of Islamic and Middle Eastern Finance and Management, 1 (3), p. 191-209.

Dusuki, Asyraf Wajdi., \& Abdullah, Nurdianawati Irwani. 2007. Why Do Malaysian Customers Patronise Islamic Banks?. International Journal of Bank Marketing, 25(3), p. 142-160.

Edison, Emron., Anwar, Yohny., \& Komariyah, Imas. 2016. Manajemen Sumber Daya Manusia : Strategi dan Perubahan dalam Rangka Meningkatkan Kinerja Pegawai dan Organisasi. Alfabeta. Bandung.

Fauzi, Rahmat. 2009. Analisis Kualitas Pelayanan Di Baitul Mall Wat
Tamwil (BMT) dengan Quality Function Deployment (QFD) (Studi Kasus Pada BMT Arafah). Skripsi, Fakultas Ekonomi Universitas Sebelas Maret.

Flavian, C., Torres, E. and Guinaliu, M. 2004. Corporate Image Measurement: A Further Problem for The Tangibilization of Internet Banking Services. International Journal of Bank Marketing, 22(5), p. 366-384.

Hoffman, K. Douglas., \& Bateson, John E.G. 2002. Essentials of Marketing of Services: Concepts, Strategies and Cases. Horcourt Colledge Publisher. Philadelphia.

Jabnoun, Nacera., \& Khalifa, A. 2005. A Customized Measure of Service Quality in The UAE. Managing Service Quality, 15(4), p. 374-388.

Jabnoun, Naceur., \& Al-Tamimi, Hussein A. Hassan. 2003. Measuring Perceived Service Quality at UAE Commercial Banks. International Journal of Quality \& Reliability Management, 20(4), p. 458-472.

Jayawardhena, Chanaka. 2004. Measurement of Service Quality in Internet Banking: The Development of an Instrument. Journal of Marketing Management, 20(1-2), p. 185-207.

Joseph, M., McClure, C., \& Joseph, B. 1999. Service Quality in The Banking Sector: The Impact of Technology on Service Delivery. International Journal of Bank Marketing, 17(4), p. 182-193.

Kotler, Philip. 1999. Manajemen Pemasaran di Indonesia Analisis, Perencanaan, Implementasi dan Pengendalian. Salemba Empat. Jakarta.

Krisnandi, Herry., \& Saputra, Nanda Agung. 2021. Kompetensi, Komunikasi, Kedisiplinan, dan Lingkungan Kerja terhadap Kinerja Karyawan. 
Oikonomia : Jurnal Manajaemen, 17(1), p. 13-26.

Kumar, M., Kee, F.T. \& Charles, V. 2010. Comparative Evaluation of Critical Factors In Delivering Service Quality of Banks: An Application of Dominance Analysis In Modified Servqual Model. International Journal of Quality \& Reliability Management, 27(3), p. 351-377.

Lee, H., Lee, Y., \& Yoo, D. 2000. The Determinants of Perceived Service Quality and Its Relationship With Satisfaction. Journal of services marketing, 14(3), p. 217-231.

Lupiyoadi, Rambat. 2001. Manajemen Pemasaran Jasa. Salemba Empat. Jakarta.

Newman, K. 2001. Interrogating Servqual: A Critical Assessment of Service Quality Measurement in a High Street Retail Bank. International Journal of Bank Marketing, 19(3), p. 126-139.

Parasuraman, A Parsu., Zeithaml, Valarie. A., \& Berry, Leonard L., 1991. Reassessment of Expectations as a Comparison Standard in Measuring Service Quaiity: Implications for Furtiier Research. Journal of Retailing, 67(4), p. 420-450.

Sedarmayanti. 2015. Manajemen Sumber Daya Manusia. Refika Aditama. Bandung.

Supranto, J. 2011. Pengukuran Tingkat Kepuasan Pelanggan, Untuk Menaikkan Pangsa Pasar. Rineka Cipta. Jakarta.

Tyas, Rizqa Ramadhaning., \& Setiawan, Ari. 2012. Pengaruh Lokasi dan Kualitas Pelayanan terhadap Keputusan Nasabah untuk Menabung di BMT Sumber Mulia Tuntang. Jurnal Muqtasi, 3(2), p. 277-297.

Vera, J., \& Trujillo, A. 2013. Service Quality Dimensions and Superior Customer
Perceived Value in Retail Banks: An Empirical Study on Mexican Consumers. Journal of Retailing and Consumer Services, 20(6), p. 579-586. 